\title{
ANTIBIOTIC SUSCEPTIBILITY OF E. COLI O157:H7 ISOLATED FROM BEEFBURGER
}

Naser A. Al-Wabel

Department of Veterinary Medicine, Faculty of Agriculture and Veterinary Medicine, Qassim University, Saudi Arabia

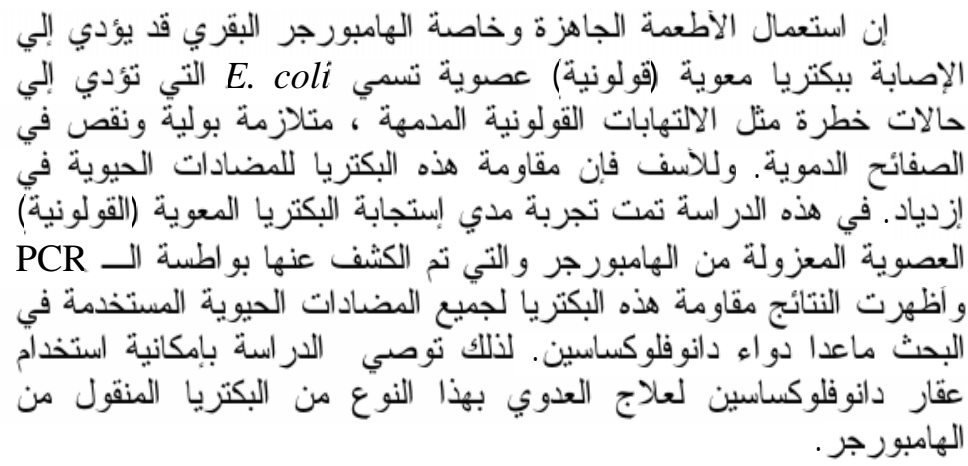

E. coli transmitted from under-cooked hamburger may cause life threatening conditiosn including hemorrhagic colitis, hemolytic uremic syndrome and thrombotic-thrombocytopaenic purpurea. Unfortunately, the emergence of resistance has become increased. Therefore, the antimicrobial susceptibility of the causative strain E. coli "O ${ }_{157}: H_{7}$ " was determined in this study. Results showed that E. coli $\mathrm{O}_{157}: \mathrm{H}_{7}$ was resistant to all tested antibiotics except danofloxacin. Therefore, this study recommend the use of danofloxacin in controlling infections caused by E. coli transmitted from hamburger.

\section{INTRODUCTION}

E.coli $\mathrm{O}_{157}: \mathrm{H}_{7}$ attracted attention not only because food-borne transmission is more common, but also because it can cause lifethreatening conditions, hemorrhagic colitis (HC) [inflammation of the colon with bleeding], hemolytic uremic syndrome (HUS) [blood in the urine, kidney failure] and thrombotic thrombocytopaenic purpura (TTP) [loss of blood platelets $]^{1}$. The majority of outbreaks have resulted from the transmission of the organism through the consumption of beef, 
most commonly, under-cooked contaminated ground beef (specially hamburger) thus, the term Hamburger Disease $^{2 \& 3}$. Ruminants are important reservoirs for E. coli $\mathrm{O}_{157}: \mathrm{H}_{7}{ }^{4}$.

The emergence of antibiotic resistance among important foodborne pathogens like E. coli $\mathrm{O}_{157}: \mathrm{H}_{7}$ has become an important issue with regard to food safety. Epidemiological studies suggest an association between the use of antibiotics in animals and the isolation of resistant bacteria from the same animals ${ }^{5}$. A further complication is the isolation of E. coli $\mathrm{O}_{157}: \mathrm{H}_{7}$ strains exhibiting resistance of commonly used antibiotics ${ }^{6}$.

However, recent studies have revealed a trend toward increased resistance to commonly used antibiotics. For example, of $56 \mathrm{E}$. coli 0157:H7 isolates collected between 1984 and 1987, all were susceptible to the antibiotics tested; however, 13 of 176 isolates (7.4\%) isolated between 1989 and 1991 were resistant to streptomycin, sulfisoxazole and tetracycline ${ }^{6}$

Meng et al. ${ }^{7}$ reported that E. coli $\mathrm{O}_{157}: \mathrm{H}_{7}$ and $\mathrm{O}_{157}: \mathrm{NM}$ have developed resistance to antibiotics (streptomycin, sulfisoxazole and tetracycline) and they concluded that research was needed to define mechanisms of antibiotic resistance in E. coli $\mathrm{O}_{157}: \mathrm{H}_{7}$ and to minimize the development of resistant.

E. coli $\mathrm{O} 157$ isolates revealed high rate of resistance to Benzyl penicillin, sulphaquinoxalin, spectinomycin and combination of kitassamycin \& amoxacillin ${ }^{8}$.

Antimicrobial resistance is one of the main concerns for health professionals dealing with bacterial disease. The current trend worldwide is to reduce antibiotic use in animal production in favor of good husbandry practices and vaccination, as means to raise healthierv animals.

\section{MATERIALS AND METHODS}

\section{Bacterial strain}

E. coli $\mathrm{O}_{157}: \mathrm{H}_{7}$ strain that isolated from beefburger sample and identified by PCR assay.

Antibiotic sensitivity test was carried out according to Piddock ${ }^{9}$.

The following antibiotic discs were tested: Amikine (AK) 30 ug, Amoxil (AMX) 25 ug, Ampicillin (AM) $10 \mathrm{ug}$, Cefobid (CFP) $75 \mathrm{ug}$, Cefoperazone (CFP) 75 ug, Cefotaxime (CTX) 30 ug, Cephalotin (CF) 30 ug, Chloramfhenicol (C) 30 ug, Danofloxacin (DFX) 5 ug, Doxycycline (D) 30 ug, Erythromycin (E) 15 ug, Garamycin (GM) 10ug, Oxytetracycline (OT) 30 ug, Penicillin (P) $10 \mathrm{ug}$, Polymexin B (PB) 300 ug, Rimactan (rifampiicin) (Rfa) 30 ug, Sulphamethaxozole (SX) 30 ug, Sulphamethazole/trimethoprim (SXT) 25 ug, Tetracycline (TE) 30 ug, Trimethoprim TM 5 ug.

For sensitivity testing, nutrient agar plates not less than $3 \mathrm{~mm}$ in thickness were inoculated uniformly by $\left(1 \times 10^{7} \mathrm{cfu} / \mathrm{ml}\right.$ agar $)$ from overnight broth cultures. The plates were then 
allowed to dry in inverted position in the incubator at $37^{\circ} \mathrm{C} / 30 \mathrm{~min}$. Subsequently the antibiotic discs were placed on the surface of the agar using sterile forceps, with a distance of a few centimeters in between. After overnight incubation of the plates at $37^{\circ} \mathrm{C}$, the total diameter of the zone of inhibition was measured using a caliper. The antibiotics were classified into resistant, intermediate and susceptible according to the manufacture directions.

\section{RESULTS}

Table 1: Antimicrobial susceptibility determinations of E. coli $\mathrm{O}_{157}: \mathrm{H}_{7}$.

\begin{tabular}{|l|c|c|c|c||}
\hline \multirow{2}{*}{\multicolumn{1}{|c|}{ Antibiotic }} & \multirow{2}{*}{$\begin{array}{c}\text { Disc } \\
\text { concn }\end{array}$} & \multicolumn{3}{c|}{ Inhibition zone diameters } \\
\cline { 3 - 6 } & $30 \mathrm{ug}$ & + & - & - \\
\hline Amikine (AK) & $25 \mathrm{ug}$ & + & - & - \\
\hline Amoxil (AMX) & $10 \mathrm{ug}$ & + & - & - \\
\hline $\begin{array}{l}\text { Ampicillin } \\
\text { (AM) }\end{array}$ & & & & - \\
\hline Cefobid (CFP) & $75 \mathrm{ug}$ & + & - & - \\
\hline Cefoperazone (CFP) & $75 \mathrm{ug}$ & + & - & - \\
\hline Cefotaxime (CTX) & $30 \mathrm{ug}$ & + & - & - \\
\hline Cephalotin (CF) & $30 \mathrm{ug}$ & + & - & - \\
\hline Chloramfhenicol (C) & $30 \mathrm{ug}$ & + & - & - \\
\hline Danofloxacin (DFX) & $5 \mathrm{ug}$ & - & - & + \\
\hline Doxycycline (D & $30 \mathrm{ug}$ & + & - & - \\
\hline Erythromycin (E) & $15 \mathrm{ug}$ & + & - & - \\
\hline Garamycin (GM) & $10 \mathrm{ug}$ & + & - & - \\
\hline Oxytetracycline (OT) & $30 \mathrm{ug}$ & + & - & - \\
\hline Penicillin (P) & $10 \mathrm{ug}$ & + & - & - \\
\hline Polymexin B (PB) & 300 & + & - & - \\
\hline Rimactan (rifampiicin) (Rfa) & $30 \mathrm{ug}$ & + & - & - \\
\hline Sulphamethaxozole (SX) & $30 \mathrm{ug}$ & + & - & - \\
\hline $\begin{array}{l}\text { Sulphamethazole/trimethoprim } \\
\text { (SXT) }\end{array}$ & $25 \mathrm{ug}$ & + & - & - \\
\hline Tetracycline (TE) & $30 \mathrm{ug}$ & + & - & - \\
\hline Trimethoprim TM & $5 \mathrm{ug}$ & + & - & - \\
\hline
\end{tabular}




\section{DISCUSSION}

Drug resistance was detected in $E$. coli 0157:H7 (Table 1). The results of this study revealed that $E$. coli 0157:H7 was resistant to all tested antibiotics except Danofloxacin. These obtained results were in agreement with most studies and reports which emphasized on the development of antimicrobial resistant of E. coli $0157: \mathrm{H}^{5-8}$.

The data show that Danofloxacin (DFX) should be effective in control of E. coli $0157: \mathrm{H} 7$ as it gives very large inhibition zone (32 mm).

\section{REFERENCES}

1- R. L. Buchanan and M. P. Doyle, Food Technol., 51, 10, 69 (1997).

2- N. Le Saux, J. S. Spika and B. Friesen, J. Infect. Dis., 167, 500 (1993).

3- M. P. Doyle, T. Zhao, J. Meng and S. Zhao, "E. coli $\mathrm{O}_{157}: \mathrm{H}_{7}$. In:
Food Microbiology, Fundamentals and Frontiers". M. P. Doyle, L. R. Beuchat and T. J. Montville (Ed.). American Society for Microbiology (ASM) Press, Washington, DC, 1997, pp. 171-191.

4- D. H. Rice, D. D. Hancock and T. E. Besser, Vet. Rec., 137, 524 (1995).

5- M. L. Cohen and R. V. Tauxe, Science, 234, 964 (1986).

6- H. H. Kim, M. Samadpour, L. Grimm, C. R. Clausen, T. E. Besser, M. Baylor, J. M. Kobayashi, M. A. Neill, F. D. Schoenknecht and P. I. Tarr, J. Infect. Dis., 170, 1606 (1994).

7- J. Meng, S. Zhao, M. P. Doyle and S. W. Joseph, J. Food Prot., 61, 11, 1511 (1998).

8- A. A. Asmaa-Hussein, S. M. Amal-Sayed and R. S. Ibrahim, $10^{\text {th }}$ Sci. Cong., Fac. Vet. Med., Assiut Univ., Egypt (2002).

9- L. J. Piddock, Appl. Bacteriol., 68, 307 (1990). 